\title{
Developmental neurotoxicity testing with human embryonic stem cell-derived in vitro systems: the novel FP7 ESNATS tests are available
}

\author{
H. M. Bolt
}

Published online: 29 November 2012

(c) Springer-Verlag Berlin Heidelberg 2012

Reproductive toxicity testing is a cutting-edge topic in toxicology (van Thriel and Stewart 2012; Coccini et al. 2012; Zimmer et al. 2012). Clearly, more accurate and faster test systems are required (Kadereit et al. 2012; van Thriel et al. 2012; Frimat et al. 2010). Therefore, the EU has initiated the FP7 research consortium, ESNATS, that aims at developing toxicity in vitro test systems based on human embryonic stem cells (hESC). In this issue of the Archives of Toxicology, the ESNATS consortium presents for the first time its novel hESC-based systems (Krug et al. 2012; Meganathan et al. 2012): the ESNATS tests for developmental neurotoxicity are finally available! The authors established protocols, which re-capitulate the different periods of differentiation of stem cells on the path to neurons: (1) establishment of the germ layers (2) neural induction (3) early neurogenesis, and (4) neurite growth. Differentiating embryonic stem cells in vitro show similar waves of gene expression as during embryonic development in vivo (Gaspar et al. 2012; Krug et al. 2012; Zimmer et al. 2011a, b). Therefore, transcriptomics represents a promising approach to detect perturbations of normal gene expression in differentiating stem cells. As a proof of concept, the authors tested two model compounds known to cause reproductive toxicity and developmental neurotoxicity in humans, namely valproic acid and methyl mercury. Indeed, both compounds caused characteristic and specific gene expression alterations in the novel test systems in contrast to D-mannitol that was used as a negative control compound. Only little overlap between genes

\section{H. M. Bolt ( $\square)$}

Leibniz Institut für Arbeitsforschung an der TU Dortmund, Leibniz Research Centre for Working Environment and Human Factors (IfADo), Ardeystrasse 67, 44139 Dortmund, Germany e-mail: bolt@ifado.de altered by valproic acid and methyl mercury was obtained. Interestingly, analysis of overrepresented transcription factor-binding sites demonstrated a large overlap of transcription factors involved in the response to both compounds. This led the authors to propose a novel concept of a 'common response' and 'compound specific responses'. Clearly, further compounds have to be tested in the future to confirm the novel hypothesis. The manuscript of Krug and colleagues marks a historical milestone in reproductive and neurotoxicity in vitro testing. However, the hunt for the best test systems and most predictive signatures has only just begun.

\section{References}

Coccini T, Roda E, Castoldi AF, Poli D, Goldoni M, Vettori MV, Mutti A, Manzo L (2012) Developmental exposure to methylmercury and 2,2',4,4',5,5'-hexachlorobiphenyl (PCB153) affects cerebral dopamine D1-like and D2-like receptors of weanling and pubertal rats. Arch Toxicol 85(10):1281-1294

Frimat JP, Sisnaiske J, Subbiah S, Menne H, Godoy P, Lampen P, Leist M, Franzke J, Hengstler JG, van Thriel C, West J (2010) The network formation assay: a spatially standardized neurite outgrowth analytical display for neurotoxicity screening. Lab Chip 10(6):701-709

Gaspar JA, Doss MX, Winkler J, Wagh V, Hescheler J, Kolde R, Vilo J, Schulz H, Sachinidis A (2012) Gene expression signatures defining fundamental biological processes in pluripotent, early, and late differentiated embryonic stem cells. Stem Cells Dev 21(13):2471-2484

Kadereit S, Zimmer B, van Thriel C, Hengstler JG, Leist M (2012) Compound selection for in vitro modeling of developmental neurotoxicity. Front Biosci 17:2442-2460

Krug AK, Kolde R, Gaspar JA, Rempel E, Balmer NV, Meganathan K, Vojnits K, Baquié M, Waldmann T, Ensenat-Waser R, Jagtap S, Evans R, Julien S, Peterson H, Zagoura D, Kadereit S, Gerhard D, Sotiriadou I, Heke M, Natarajan K, Henry M, 
Winkler J, Marchan R, Stoppini L, Bosgra S, Westerhout J, Verwei M, Vilo J, Kortenkamp A, Hescheler J, Hothorn L, Bremer S, van Thriel C, Krause KH, Hengstler JG, Rahnenführer J, Leist M, Sachinidis A (2012) Human embryonic stem cell derived test systems for developmental neurotoxicity: a transcriptomic approach. Arch Toxicol (this issue)

Meganathan K, Jagtap S, Wagh V, Winkler J, Gaspar JA, Hildebrand D, Trusch M, Lehmann K, Hescheler J, Schluter H, Sachinidis A (2012) Identification of thalidomide-specific transcriptomics and proteomics signatures during differentiation of human embryonic stem cells. PLoS ONE 7(8):e44228

van Thriel C, Stewart JD (2012) Developmental neurotoxicity: the case of perfluoroalkylated compounds. Arch Toxicol 86(9): 1333-1334

van Thriel C, Westerink RH, Beste C, Bale AS, Lein PJ, Leist M (2012) Translating neurobehavioral endpoints of developmental neurotoxicity tests into in vitro assays and readouts. Neurotoxicology 33(4):911-924

Zimmer B, Kuegler PB, Baudis B, Genewsky A, Tanavde V, Koh W, Tan B, Waldmann T, Kadereit S, Leist M (2011a) Coordinated waves of gene expression during neuronal differentiation of embryonic stem cells as basis for novel approaches to developmental neurotoxicity testing. Cell Death Differ 18(3):383-395

Zimmer B, Schildknecht S, Kuegler PB, Tanavde V, Kadereit S, Leist M (2011b) Sensitivity of dopaminergic neuron differentiation from stem cells to chronic low-dose methylmercury exposure. Toxicol Sci 121(2):357-367

Zimmer B, Lee G, Balmer NV et al (2012) Evaluation of developmental toxicants and signaling pathways in a functional test based on the migration of human neural crest cells. Environ Health Perspect 120(8):1116-1122 